Metals and Ceramics Division

\title{
ATOM PROBE FIELD ION MICROSCOPY AND RELATED TOPICS: \\ A BIBLIOGRAPHY 1989
}

M. K. Miller

A. R. Hawkins

K. F. Russell

Date Published - December 1990

Prepared for the

DOE Office of Basic Energy Sciences

KC 0201010

\author{
Prepared by the \\ OAK RIDGE NATIONAL LABORATORY \\ Oak Ridge, Tennessee 37831-6285 \\ managed by \\ MARTIN MARIETTA ENERGY SYSTEMS, INC. \\ for the \\ U.S. DEPARTMENT OF ENERGY \\ under Contract DE-AC05-84OR21400
}




\section{PREFACE}

This bibliography includes references related to the following topics: atom probe field ion microscopy (APFIM), field ion microscopy (FIM), field emission microscopy (FEM), liquid metal ion sources (LMIS), scanning tunneling microscopy (STM), and theory. Techniqueorientated studies and applications are included.

This bibliography covers the period 1989. Previous publications, Atom Probe Field-ion Microscopy and Related Topics: A Bibliography 1978-1987, complied by M. K. Miller and A. R. McDonald, ORNL/TM-11157, Atom Probe Field-Ion Microscopy and Related Topics: A Bibliography 1988, complied by M. K. Miller and A. R. Hawkins, ORNL/TM-11370, Oak Ridge National Laboratory, Oak Ridge, TN 37831-6285, and Field-Ion Microscopy and Related Techniques, A Bibliography: 1951-1978, compiled by R. E. Thurstans and J. M. Walls, published by Warwick, Birmingham, contains the papers published prior to this period.

The references contained in this document were compiled from a variety of sources including computer searches and personal lists of publications. To reduce the length of this document, the references have been reduced to the minimum necessary to locate the articles. The references are listed alphabetically by authors in the year in which they were published. This year differs from previous editions in that the publications are subdivided into the categories listed in paragraph one above.

We would like to thank Dr. G. D. W. Smith of Oxford Uaiversity, Dr. J. Bentley of Oak Ridge National Laboratory (ORNL), and M. Alexander of the ORNL Central Library for their stoic efforts in the preparation of this document. We would also like to thank the many authors for supplying their personal publications lists and we apologize for any errors or omissions that may have occurred in compiling this document.

M. K. Miller, A. R. Hawkins, and K. F. Russell

Metals and Ceramics Division 
CONTENTS

1989

Atom Probe Field Ion Microscopy $\ldots \ldots \ldots \ldots \ldots \ldots \ldots \ldots \ldots \ldots \ldots \ldots$

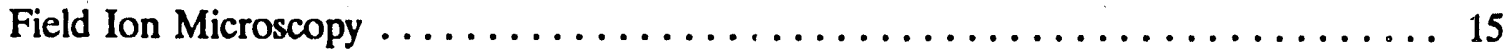

Field Emission Microscopy $\ldots \ldots \ldots \ldots \ldots \ldots \ldots \ldots \ldots \ldots \ldots \ldots \ldots \ldots \ldots \ldots \ldots$

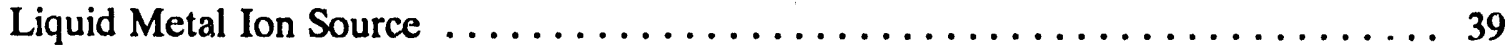

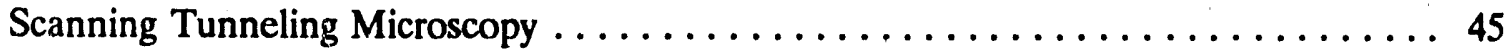

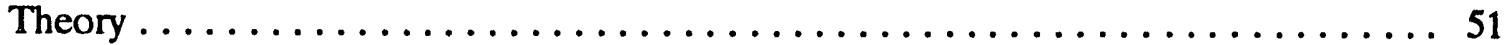

ADDENDUM for $1978-87$ and $1988 \ldots \ldots \ldots \ldots \ldots \ldots \ldots \ldots \ldots \ldots \ldots \ldots \ldots \ldots \ldots \ldots \ldots \ldots$

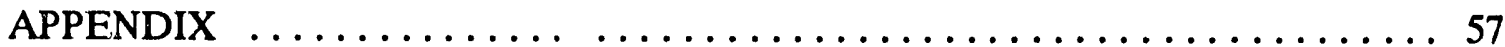


1989 
1 Composition in binary $\mathrm{Al}-\mathrm{Li}$ alloys

2. Atom-probe field-ion microscopy of grain boundary segregation

3 An APFIM study of the ageing behaviour of U-6.0 wt \% Nb

4 Some unresolved issues in phase transformations - the role of microanalysis

5 FIM atom probe investigation of long period superstructures in $\mathrm{Cu}_{3 \pm x} \mathrm{Pd}$

6 Toward a tomographic atom-probe

7 Atom-probe study of some fine-scale features in nickel base superalloys

8 A combined TEM/APFIM approach to the study of phase transformations: phase identification in the $\mathrm{Fe}-\mathrm{Be}$ system

9 APFIM/TEM characterization of precipitation in alloy 718
Al-Kassab, T.
Menand, A.
Auger, P
Haasen, P.

Alvensleben, L.v. Haasen, $\mathrm{P}$.
J. de Phys. (1989)

C8-50, 419-24

Characterization of the Structure and Chemistry of Defects in Materials, Mat.

Res. Sos. Symp. Proc. (1989) 138, 479-84, Larson, B.C., Ruhle, M. and Seidman, D.N. eds., MRS, Pittsburgh, PA

Beverini, G. Edmonds, D.V.

J. de Phys. (1989) C8-50, 429-36

Bhadeshia, H.K.D.H. J. de Phys. (1989) C8-50, 389-94

Blavette, D. J. de Phys. (1989) Chambreland, S. Loiseau, A. Planes, J.

Ducastelle, F.

Bostel, A. Blavette, D. Menand, A.

Sarrau, J.M.

Buchon, A. Bostel, A. C8-50, 365-70
Blavette, D.

Burke, M.G. Miller, M.K.

(1989) 스, 199-209

Burke, M.G. Miller, M.K.
Ultramicroscopy

J. de Phys. (1989)

C8-50, 501-6

J. de Phys. (1989)

C8-50, 401-6

J. de Phys. (1989)

C8-50. 395-400 
10 Oxygen concentration of $\mathrm{Eu}_{1} \mathrm{Ba}_{2} \mathrm{Cu}_{3} \mathrm{O}_{7 \cdot x}$ in vacuum: an atom probe study II

11 APFIM analysis of composite magnetic thin films

12 Characterization of ultrafine microstructures using a position-sensitive atom probe

13 Materials analysis with a position-sensitive atom probe

14 Surface analysis with a position-sensitive atom probe

15 Visualisation and analysis of 3-dimensional atom probe data

16 Atom probe characterization of $\mathrm{Co} /$ transition-metal multilayer structures

17 Position-sensitive atom probe analysis of multiple quantum well structures
Camus, P.P.

Elswijk, H.B.

Melmed, A.J.

Camus, P.P.

Shull, R.D.

Melmed, A.J.

Cerezo, A.

Grovenor, C.R.M.

Hetherington, M.G. Microstruct., Mat.

Shallock, B.A.

Smith, G.D.W.

Cerezo, A.

Godfrey, T.J.

Grovenor, C.R.M.

Hetherington, M.G.

Hoyle, R.M.

Jakubovics, J.P.

Liddle, J.A.

Smith, G.D.W.

Worrall, G.M.

Cerezo, A.

Godfrey, T.J.

Grovenor, C.R.M

Smith, G.D.W.

Cerezo, A.

Hetherington, M.G. C8-50, 523-8

Cerezo, A.

J. de Phys. (1989)

Hetherington, M.G. C8-50, 349-54

Petford-Long, A.K.

Cerezo, A.

Liddle, J.A.

Microscopy of

Grovenor, C.R.M.
Semiconducting

Materials VI (1989)

75-80, Cullis, A.G. and Hutchison, J.L. eds., Inst. Phys. , Bristol 
18 Application of a position sensitive atom probe to the analysis of the chemistry and morphology of multi-quantum well interfaces
19 Proc. 36th Int. Field Emiss. Symp. (1989), Oxford, Great Britain

20 The initial stage of aging iron-nitrogen martensite
Cerezo, A.

Liddle, J.A.

Grovenor, C.R.M.

Chris, R.M.

Norman, A.G.

Smith, G.D.W.
Cerezo, A.

Miller, M.K.

Smith, G.D.W.

editors

Cheng, L.

Stark, I.

Korevaar, B.M.

Mittemeijer, E.J.

Smith, G.D.W.

Cornell, $\mathbf{R}$

Smith, G.D.W.

Cranstoun, G.K.L

Drachsel, W.

Alvensleben, L.v.

Melmed, A.J.

Elswijk, H.B.

Melmed, A.J.

Camus, P.P.
Characterization of the Structure and

Chemistry of Defects in Materials, Mat.

Res. Soc. Symp. Proc. (1989) 138, 335-40, Larson, B.C., Ruhle, $M .$, and Seidman,

D.N., eds., High-Resolution Microscopy of Materials, Mat. Res. Soc. Symp. Proc. (1989) 139, 45-50, Krakow, W., Ponce, F.A., and Smith, D.J., eds., MRS,

Pittsburgh, PA

J. de Phys. (1989)

C8-50

High Nitrogen Steels (1989) 453, 97-101, Proc. Intl. Conf., Lille, France, 1988, Fock, J. and Hendry, A., eds., Institute of Metals, London

J. Chem. Technol. Biotechnol. (1989) 44, 9-17

J. de Phys. (1989)

C8-50, 541-6

Appl. Phys. Lett. (1989) 55, 2667-9 $\mathrm{Eu}_{1} \mathrm{Ba}_{2} \mathrm{Cu}_{3} \mathrm{O}_{7-x}$ in
atom probe study 
24 Field adsorption of helium and neon on tungsten: an energy-resolved atom-probe study

25 Chromium concentration in and around ferrite-austenite phase boundaries in duplex stainless steels

26 Observation of epitaxial overlayer of metals at atomic level

27 Field ion microscopy and atom probe microanalysis of vanadium

28 Atom probe studies of the composition of low-temperature oxides on (100) silicon and gallium arsenide surfaces

29 Position sensitive atom probe studies of the composition of 0 and $\boldsymbol{\theta}^{\prime}$ precipitates in $\mathrm{Al}-\mathrm{Cu}-\mathrm{Mg}$-Ag alloys

30 Some aspects of the measurement of composition in the atom probe

31 Studies on age-hardenable aluminum-alloys by atom-probe field-ion microscope

32 Atom-probe study of selective oxidation of $\mathrm{Ni}$ from $\mathrm{Cu}-\mathrm{Ni}$ alloy
Ernst, N.

Surf. Sci. (1989) 219, $1-32$

Gadgil, V.J.

Swens, J.J.

Kolster, B.H.

J. de Phys. (1989)

C8-50, 361-4

Gao, Q.J.

Tsong, T.T.

Acta Metall. Sinica (1989) 2, 231-6

Godfrey, T.J.

Setna, R.P.

J. de Phys. (1989)

Smith, G.D.W.

C8-50, 381-8

Grovenor, C.R.M.

Cerezo, $\mathrm{A}$.

J. Appl. Phys. (1989)

65, 5089-95

Grovenor, C.R.M. J. de Phys. (1989)

Shollock, B.A.

C8-50, 377-80

Knowles, K.M.

Hetherington, M.G.

Miller, M.K.

J. de Phys. (1989)

Hirano, $\mathrm{K}$.

C8-50, 535-40

Bull. Mater. Sci. (1989) 12, 313-23

Hono, $\mathrm{K}$.

Nakamura, M.

Pickering, H.W.

Sakurai, T.
High-Resolution

Microscopy of

Materials, Mat. Res.

Soc. Symp. (1989)

139, 283-7, Krakow, W., Ponce, F.A., and

Smith, D.J., eds., MRS, Pittsburgh, PA 
33 Oxygen segregation and oxidation on a copper surface

34 An atom-probe field-ion microscope study of the initial stages of oxidation of copper and copper-iron alloy

35 Atom-probe analysis of GP zones in an $\mathrm{Al}-1.7$ at. \% $\mathrm{Cu}$ alloy

36 Effect of aluminum level on boron clustering in $\mathrm{Ni}_{3} \mathrm{Al}$
37 The structure and composition of a $\Sigma \sim 9$ interface in a $\mathrm{Mo}(\mathrm{Re})$ alloy via transmission electron and atom-probe field-ion microscopies

38 FIM - atom probe investigation of melt-spun permanent magnets based on $\mathrm{NdFeB}$

39 Atom probe microcharacterization of grain boundary carbide precipitation and impurity-segregation in type 304 stainless steel

40 Atomic-level studies of superconducting and nonsuperconducting $\mathrm{YBa}_{2} \mathrm{Cu}_{3} \mathrm{O}_{7 \cdot x}$
Hono, $\mathrm{K}$.

Pickering, H.W.

Hashizume, T.

Kamiya, I

Sakurai, T.

Hono, $\mathrm{K}$.

Pickering, H.W.

Sakurai, T.

Appl. Surf. Sci.

(1989) 35, 327-44

Hono, $\mathrm{K}$.

Sakurai, T.

Pickering, H.W.

Horton, J.A.

Miller, M.K.

Liu, C.T.

George, E.P.

Bentley, J.

Hu, J.G.

Kuo, S.M.

Seki, A.

Krakauer, B.W.

Seidman, D.N.

Hutten, A.

Haasen, $P$.

Ishikawa, Y.

Yoshimura, T.

Koguchi, Y.

Takahashi, K.

Kellogg, G.L. Brenner, S.S.
J. de Phys. (1989)

C8-50, 337-42

Metall. Trans. (1989)

20A, 1585-91

High-Temperature Ordered Intermetallic Alloys III, Mat. Res. Soc. Symp. Proc. (1989) 133, 89-97, Liu, C.T., Taub, A.I., Stoloff, N.S., and Koch, C.C., eds., MRS, Pittsburgh, PA

Scripta Metall. (1989) 23, 2033-8

Boshoku Gijutsu (1989) $\underline{38}$, 586-92
Appl. Phys. A: Solids and Surfaces (1989) 48, 197-201 
41 Novel applications of the field ion microscope and atom probe

4. Investigations of reactions between pure refractory metals and light gases with the field-ion microscope and atom probe

43 Atom probe with compensation for the scatter in the ion kinetic energies

44 Gold-germanium contacts on gallium arsenide

45 Atom probe analysis of $\mathrm{YBa}_{2} \mathrm{Cu}_{3} \mathrm{O}_{7 \cdot \mathrm{x}}$ - single crystals

46 Position-sensitive atom probe analysis of multi-quantum well structures

47 Position-sensitive atom probe and STEM analysis of the microchemistry of gallium indium arsenide/indium phosphide quantum wells
Kellogg, G.L.

Krautz, E. Haiml, G.

Kudryavtsev, A.N. Nikonenko, N.V. Dubenskii, B.M. Shmikk, D.V.

Kvist, A. $\mathrm{Hu}$, Q.H. Andren, $\mathrm{H}-\mathrm{O}$.

Leisch, $M$. Eisl, M.

Schweiger, E. Leising, G.

Liddle, J.A. Cerezo, A. Grovenor, C.R.M.

Liddle, J.A. Long, N.J.

Norman, A.G. Cerezo, A. Grovenor, C.R.M.
Microbeam Analysis1989, 201-206A, Russell, F.E., ed., San Francisco Press, $\mathrm{CA}$

High Temp. - High Pressures (1989) 21, 515-23

Pisma Zh. T. (1989) 15, 33-6

J. de Phys. (1989)

C8-50, 465-70

J. de Phys. (1989)

C8-50, 481-6

J. de Phys. (1989)

C8-50, 437-42

Chem. Defects

Semicond.

Heterostruct., Mat. Res. Soc. Symp. Proc. (1989) 148, 377-82, Kawabe, M., Sands, T.D., Weber, E.R., and Williams, R.S., eds., MRS, Pittsburgh, PA

Liddle, J.A.

Norman, A.G. Cerezo, A.

Appl. Fhys. Lett. (1989) $\underline{54}, 1555-7$ atom probe to the study of the microchemistry and morphology of quantum well interfaces

Grovenor, C.R.M. 
49 A new multifunction field ion microscope

The composition fluctuation in an $\mathrm{Fe}_{46} \mathrm{Ni}_{31} \mathrm{~V}_{1} \mathrm{Si}_{8} \mathrm{~B}_{14}$ glass

51 Characterization of the oxide film on molytdenum

52 Heterogeneity in iron-nickel-boron $\left(\mathrm{Fe}_{82.3} \mathrm{Ni}_{1.7} \mathrm{~B}_{16}\right)$ glass

53 The various charge states of gold ions in the field evaporation process

54 Composition fluctuations in III-V semiconductors

55 Pulsed laser atom probe characterization of silicon carbide

56 Atom probe field-ion microscopy and related topics: a bibliography 1988

57 Atom probe analysis of $\boldsymbol{\beta}^{\prime}$ precipitation in a model iron-based $\mathrm{Fe}-\mathrm{Ni}$-Al-Mo superalloy
Liu, W.

Ren, D.M.

Liu, Z.G.

Cao, Y.N.

Chen, Y.

Liu, Z.G.

Chen, Y.

Wen, X.Z.

Liu, Z.G.

$\mathrm{Wu}$, H.J.

Chen, Y.

Wu, X.

Qin, X.Y.

Lu, H.

Bao, C.L.

Yiong, Y.Y.

J. Phys. D: Appl. Phys. (1989) 22,

948-51

MacKenzie, R.A.D.

Liddle, J.A.

Grovenor, C.R.M.

Cerezo, A.

Miller, M.K.

Angelini, P.

Cerezs, A.

More, K.L.

Miller, M.K.

Hawkins, A.R.

Miller, M.K.

J. Non-Cryst. Solids (1989) $\underline{109}, 262-6$

Surf. Sci. (1989) 208

L15-20

J. de Phys. (1989)

C8-50, 453-8

J. de Phys. (1989)

C8-50, 459-64

ORNL/TM-11370

(1989) Oak Ridge National Laboratory,

Oak Ridge, TN

Hetherington, M.G. $\quad$ C\&-50, 425-8
J. de Phys. (1989) 
58 Atom probe field-ion microscopy: a technique for microstructural characterization of irradiated materials on the atomic scale

59 An atom probe field-ion microscopy study of phase separation in the Twin City and Santa Catharina meteorites

60 Atom probe microanalysis: principles and applications to materials problems

61 Composition and microstructure of a nickel-based superalloy: UDIMET 720

62 The atom-probe with a field emission electron spectrometer

63 Chemical homogeneity of NiPdP metallic glasses studied by atom probe-field ion microscopy

64 Vitreous ice as a cryoprotectant for imaging atom-probe studies of adsorption phenomena at a solid-liquid interface

65 Annealing induced embrittlement and infl sence of annealing on ductile to brittle transition in metallic glass $\mathrm{Fe}_{80.7} \mathrm{~B}_{12.8} \mathrm{Si}_{3.9} \mathrm{C}_{26}$

66 The application of field ion microscope atom probe for materials science
Miller, M.K.

Metall. Trans. (1989)

Hetherington, M.G. 20A, 2651-61

Burke, M.G.

Miller, M.K.

Russell, K.F.

J. de Phys. (1989)

C8-50, 413-8

Miller, M.K.

Smith, G.D.W.

More, K.L.

Miller, M.K.

Nishikawa, $\mathrm{O}$.

Koyama, $\mathrm{H}$.

Kodama. N.

Tomitori, $\mathrm{M}$.

Oehring, M.

Z. Metallkunde

(1989) 80, $1-8$

Panitz, J.A.

J. Vac. Sci. Technol.

(1989) A7, 2850-3

Qin, X.Y.

$\mathrm{Wu}, \mathrm{X} . J$.

Shui, J.P.

Liu, Z.G.

Ren, D.
(1989) MRS, Pittsburgh, P:

Proc. 47th Ann. Meet. Electron Microsc. Soc. Amer. (1989) 280-1, Bailey, G.W., ed., San Francisco Press, CA

J. de Phys. (1989)

C8-50, 507-12
Z. Metallkunde (1989) 80, 626-9

Mater. Sci. Progress (1989) $\underline{\underline{3}, 523-9}$ 
67 A new tnethod of surface segregation analysis

68 A study of segregation and cosegregation of some platinum base alloys

69 Atom-probe analysis applied to TiC-Ni- $\mathrm{k}$ ased cemented carbides

70 Evaluation of aton prote spectra from titanium ca! tonitride

71 Statistical correction for pile-up in the atom-probe detector system

72 Atom-prohe field ion microscopy and its applications

73 f tom-probe study of the iecomposition process of an Al.Zn alloy

74 Atom-probe study of surface segregation of Pt-Rh alloys
Ren, D.

Liu, W.

Ren, D.M.

Qin, J.H.

Liu, W.

Rolander, U. Andren, H-O.

Rolander, U.

Andren, H-O.

Rolander, U. Ançren, H-O.

Sakuiai, T.

Sakai, A.

Piskering, H.W.

Sano, $N$.

Hasegawa, Y.

Hirano, $K$.

Sakurai, T.

Pickering, H.W.

Sano, N.

Sakurai, T.
Proc. 3ri' Reijing

Conf. and Exhib. on Instrum. Analysis (1989) Beijing

Proc. Intl. Workshop on Physics of Materials (1989), G9-1-5, Shenyang, People's Rep. of China

Proc. 12th Intl. Plansee Seminar (1989) 2, 379-88, Bildstein, $H$. and Ortner, H.M., eds., Metallwerk Plansee GmbH, Reutee/Tirol, Austria

J. de Phys. (1989)

C8-50, 371-6

J. de Phys. (1989)

C8-50, 529-34

Advances in Electronics and Electron Physics (1989) 20, 299 pp, Academic Fress

Scripta Metall. (1989) 23, 231-6

J. de Phys. (1989)

C\&-50, 321-8 
75 Study of the structure and chemistry of point, line and planar imperfections via field-ion and atom-probe field-ion microscopy

76 A FIM atom probe study of vanadium oxidation

77 A field-ion microscopy and atom probe study of ageing behaviour of a Co-bearing maraging steel

78 The microchemistry of grain boundaries in $\mathrm{Ni}_{3} \mathrm{Al}$

79 Grain boundary chemistry in nickel base alloy 600

80 Atom probe field ion analysis of metal surface

81 Spinodal decomposition during aging of Fe-Ni-C martensites

82 Atom-probe field ion microscope analysis of surfaces of materials
Seidman, D.N.

Characterization of the Structure and Chemistry of Defects in Materials, Mat.

Res. Soc. Symp. Proc. (1989) 138, 315-28, Larson, B.C., Ruhle, $M$., and Seidman, D.N., eds., MRS, Pittsburgh, PA

Setna, R. P. Godfrey, T.J.

Smith, G.D.W.

J. Phys. Condens. Matter (1989) 1 , SB215-6

Sha, W. Cerezo, W. Smith, G.D.W.

Sieloff, D.N. Brenner, S.S. Ming-Jian, $\mathrm{H}$.

Stiller, K.

J. de Phys. (1989)

C8-50, 407-12

High-Temperature Ordered Intermetallic Alloys III, (1989) 133, 155-60, Liu, C.T., Taub, A.I., Stoloff, N.S., and Koch, C.C., eds., MRS,

Pittsburgh, PA

J. de Phys. (1989)

C8-50, 329-34

Suzuki, T.

Puretingu to Kotingu

Nishi, Y.

(1989) 9 , 64-7

Taylor, K.A.

Metall. Trans. (1989)

Chang, L.

20A, 2717-37

Olson, G.B.

Smith, G.D.W.

Cohen, $M$.

VanderSande, J.B.

Tsong, T.T.

Chen, C.

Liu, J.
J. Mater. Res. (1989)

4, 1549-59 
83 Surface analysis with pulsed-laser stimulated field desorption

84 Investigation of atomic structure and composition of yttrium barium copper oxide $\left(\mathrm{YBa}_{2} \mathrm{Cu}_{3} \mathrm{O}_{7 . x}\right)$ single crystals by means of a wide-angle atomic probe

85 Atom probe analysis of thin oxide layers on zircaloy needles

86 Direct measurement of matrix composition in zircaloy- 4

$87475^{\circ} \mathrm{C}$ embrittlement of duplex stainless steel

88 Interaction between nitrogen and substitutional elements in the austenitic phase of duplex austenitic-fe-ritic stainless steels

89 Field ion microscopy snd atom probe analysis of ion-irradiated alloys (summary)
Tsong, T.T.

Liou, $Y$.

Liu, J.

Vlasov, Y.A.

Golubev, O.L.

Samokhvalov, A.A.

Syutkin, N.N.

Tulantsev, E.F.

Chebotaev, N.M.

Shrednik, V.N.

Wadman, B. Andren, H-O. Falk, L.K.L.

Wadman, B. Andren, $\mathrm{H}-\mathrm{O}$.

Wahlberg, G. Rolander, U. Dunlop, G.L.

Wahlberg, G. Rolander, U. Andren, H-O.

Wollenberger, $\mathrm{H}$.

Kell, B.

J. de Phys. (1989)

C8-50, 303-8

Pisma Zh. T. (1989) $15,62-7$

J. Vac. Sci. Technol. (1989) A⒎ 1758-63

Proc. 8th Intl. Symp. Zirconium Nucl. Inc., ASTM STP 1023 (1989) 423-34

Proc. 8th Intl. Conf. on Strength of Metals and Alloys, Tampere, Finland, 1988, Kettunen, P.O., Lepisto, T.K., and Lehtonen, M.E., eds., Pergamon Press, Oxford, UK (1989) $\underline{3}$, 1263-6

High Nitrogen Steels (1989) 453, 163-8, Proc. Intl. Conf., Lille, France, 1988, Fock, J. and Hendry, A., eds., Institute of Metals, London

Lang, $\mathrm{R}$. Wagner, W.
J. de Phys. (1989)

C8-50, 335-6 
Atom Probe Field Ion Microscopy

90 Atom transport and phase separation in irradiated $\mathrm{Cu}-\mathrm{Ni}-\mathrm{Fe}$ alloys
Wollenberger, H.J. Characterization of the Structure and Chemistry of Defects in Materials, Mat.

Res. Soc. Symp. Proc. (1989) 138, 3-13,

Larson, B.C., Ruhle, M., and Seidman,

D.N., eds., MRS,

Pittsburgh, PA 
1 Precision ion milling of field-ion specimens

2 Experimental techniques in evaluating the dynamics of catalytic surface reactions

3 Solid-state surfaces from atomic view-studies by field-ion microscopy and mass spectrometry

4 Determination of reaction intermediates of heterogeneous catalytic reactions by field pulse desorption

5 Enhanced formation of multiply charged ions in negative ion field desorption mass spectrometry of organic compounds

6 Studies of individual nanometer-sized metallic :lusters using scanning tunneling microscopy, field emission, and field ion microscopy

7 Behavior of single Ir adatoms and small Ir clusters on Ir surfaces

8 Field ion images of some non-metallic materials
Alexander, K.B.

Angelini, $\mathrm{P}$. Miller, M.K

Block, J.H.

Block, J.H.

Block, J.H.

Abend, G.

Kruse, N.

Weimer, J.J.

Bramer-Weger, E. Thiebes, S. Rollgen, F.W.

Castro, T.

Li, Y.Z.

Reifenberger, $\mathbf{R}$.

Choi, E.

Park, S.B.

Andres, R.P.

Chen, C.L.

Tsong, T.T.

Chen, C.L.

Tsong, T.T.
J. de Phys. (1989)

Q8-50, 549-54

Dechema

Monographs - VCH

Verlagsgesellschaft

(1989) 120, 169-94

Mitteilungsblatt Chem. Gesell., DDR (1989) 뜨, 121-8

Chem. Eng. Comm.

(1989) 푸, 103-9

J. de Phys. (1989)

C8-50, 159-64

J. Vac. Sci. Technol., (1989) A7, 2845-9

J. de Phys. (1989)

C8-50, 273-8

High-Resolution

Microscopy of Materials, Mat. Res.

Soc. Symp. Proc.

(1989) 139, 181-6,

Krakow, W., Ponce,

F.A., and Smith, D.J., eds., MRS,

Pittsburgh, PA 
Field Ion Microscopy

9 Methanol adsorption and decomposition on rhodium

10 Photon induced field dcsorption of water

11 Field ion microscopy of quasicrystals
12 An advanced technique for the preparation and TEM examination of FIM specimens

13 Direct observation of atomic image of high $T_{c}$ superconductors by field ion microscopy

14 Kinetics of field evaporation of gallium phosphide in th: presence of hydrogen
Chuah, G.K.

Kruse, N.

Schmidt, W.A.

Block, J.H.

Abend, G.

Dirks, J.

Drachsel, W.

Block, J.H.

Elswijk, H.B.

DeHosson, J.T.M.

Fischione, P.E.

Haugh, J.J.

Burke, M.G.

Gao, Z.J.

Zhang, Z.X.

$\mathrm{Xu}, \mathrm{S} . \mathrm{Y}$.

Feng, S.Q.

Wang, S.Z.

Gaussman, A.

Drachsel, W.

Block, J.H.
J. Catalysis (1989)

$119,342-53$

J. de Phys. (1989)

C8-50, 153-8

Tharacterization of the Structure Chemistry of Defects in Materials, Mat.

Res. Soc. Symp. Proc. (1989) 138, 341-6, Larson, B.C., Ruhle, M., and Seidman, D.N., eds., High-Resolution Microscopy of Materials, Mat. Res. Soc. Symp. Proc. (1989) 139, 51-6, Krakow, W., Ponce, F.A., and Smith, D.J., eds., MRS,

Piitsburgh, PA

J. de Phys. (1989)

C8-50, 555-60

J. de Phys. (1989)

C8-50, 487-90

J. de Phys. (1989)

C8-50, 141-6 
Field Ion Microscopy

15 A field ion microscopy study of nickel oxide

Hono, $\mathrm{K}$.

Surf. Sci. (1989) 209,

Iwata, $\mathrm{T}$.

L109-17

Pickering, H.W.

Sakurai, T.

16 Photon-stimulated desorption of hydrogen from rhodium and nickel in high electric fields

Jaenicke, $S$.

Surf. Sci. (1989)

Dosselmann, J. 211/212, 804-12

Ciszewski, A.

Drachsel, W.

Block, J.H.

Nenzel, D.

17 High-field microscopy of the

Karpowicz, A. tungsten/polyethylene system

Surma, $\mathbf{S}$.

Surf. Sci. (1989) 213, 393-411

12 Field ion microscope and imaging atom-probe investigations of oxide formation on $\mathrm{W}$ and $\mathrm{Ir}$ field

Y.ellogg, G.L.

J. de Phys. (1989)

C8-50, 297-302

emitters

19 Direct observations of atomic mixing in $\mathrm{Pt} / \mathrm{Pd}$ surface alloy formation

Kellogg, G.L.

Schwoebel, P.R.

Surf. Sci. (1989) 224, 489-97

20 Field ion microscope investigations of atomic processes at surfaces

Kellogg, G.L.

Proc. 47th Ann.

Schwoebel, P.R.

Meet. Electron

Microsc. Soc. Amer. (1989) 228-9, Bailey,

G.W., ed., San

Francisco Press, CA

21 Pencil lead tips: a field ion and field electron emission microscopic study

Khairnar, R.S.

J. Appl. Phys. (1989)

Dharmadhikari, C.V. $\quad \underline{65}, 4735-8$

Joag, DS.

Krautz, E.

J. de Phys. (1989)

22 Field ion microscopic investigations of deposition, adhesion and field desorption of Haiml, G. C8-50, 309-15 carbides on tungsten

23 Investigations of lattice defects of metals with dissolved hydrogen by the field ion microscope

Krautz, E. Haiml, $G$.
Z. Phys. Chem. (1989) $164,1145-50$ 
24 Theory of oscillating reactions

25 Formation of Rh-subcarbonyls during the reaction of $\mathrm{CO}, \mathrm{CO}_{2}$ and $\mathrm{CH}_{3} \mathrm{OH}$ with stepped $\mathrm{Rh}$ single crystal sirfaces

26 Kinetics of adsorption, thermal desorption and dissociation of NO on rhodium, studied by pulsed field desorption

27 Observation of Rh-subcarbonyls on stepped $\mathrm{Rh}$ surfaces during catalytic reactions

28 Adatom diffusion on metals: Ir on W(110)

29 The various charge states of gold ions in the field evaporation process

30 Field evaporation of n-Ge (111) in hydrogen and decomposition of $\mathrm{GeH}_{4}$ in high electrostatic fields

31 The method of sharp-pointed shards

32 Field ion microscope image simulations for icosahedral Al-Mn

33 Field evaporation and field ion microscopy study of the morphology of phases produced as a result of low temperature phase transformations in the iron-chromium system
Kreuzer, H.J.

Dechema Monographs - VCH Verlagsgesellschaft (1989) 120, 375-89

Kruse, N. Abend, G. Block, J.H. Surf. Sci. (1989) 211/212, 1038-43

Kruse, $\mathbf{N}$. Abend, G. J. de Phys. (1989) Block, J.H. C8-50, 147-52

Kruse, N. Abend, G. Block, J.H.

J. Chem. Phys. (1989) 91, 577-83

Lovisa, M. Ehrlich, G.

J. de Phys. (1989) C8-50, 279-84

$\mathrm{Lu}, \mathrm{H}$.

Bao, C.L.

Xiong, Y.Y.

Mainka, C.

Drachsel, W.

Block, J.H.

Kozlowski, G.

Melmed, A.J.

J. de Phys. (1989) C8-50, 547-8

Melmed, A.J. J. de Phys. (1989) Elswijk, H.B. C8-50, 259-64

Fowler, H.A.

Miller, M.K. J. de Phys. (1989) C8-50, 247-52
J. Phys. D: Appl. Phys. (1989) 22, 948-51

J. de Phys. (1989) C8-50, 135-40 
Field Ion Microscopy

34 Vapor-deposition and migration of iron on tungsten tips

35 FIM observation of monolayer Pd adsorbed on W and Mo surfaces

36 Field desorption process of $\mathbf{P d}$ adlayer and adatom on W(011), $W(112)$ and $W(111)$

37 Image effects in the field ionization phenomenon

38 A combination electron/ion field emission source

39 Scanning tunneling microscope equipped with a field ion microscope
Morikawa, $\mathrm{H}$.

Hara, $T$.

Iwatsu, F.

Terao, $\mathrm{T}$.

Okuno, K.

Kim, H.

Okuno, $\mathrm{K}$.

$\mathrm{Kim}, \mathrm{H}$.

Radny, M.

Krystof, W.

Rao, K.A.

Bell, A.E.

Schwind, G.A.

Swanson, L.W.

Sakurai, T.

Hashizume, T.

Kamiya, I.

Hasegawa, Y.

Ide, $\mathrm{T}$.

Miyao, M.

Sumita, I.

Sakai, A.

Hyodo, S.

Sakurai, $\mathrm{T}$.

Ir(111) and (110) surfaces by

field ion microscopy

43 Extraction of Ir-Ir adatom interaction strengths on $\operatorname{Ir}(100)$ from field ion microscopy of iridium cluster structures
J. de Phys. (1989)

C8-50, 285-90

J. de Phys. (1989)

C8-50, 291-6

Jpn. J. Appl. Phys. (1989) 료, 1054-60

Surf. Sci. (1989) 213, 270-6

J. Vac. Sci. Technol., (1989) B7, 1793-7

J. Vac. Sci. Technol. (1989) A7, 1684-8
Sano, N.

Schmitz, R.

Rollgen, F.W.

Schutz, O.

Muller, K.

Kinzoku, (1989) $\underline{59}$, 40-7

J. de Phys. (1989)

C8-50, 243-6

J. de Phys. (1989)

C8-50, 253-8

Schwoebel, P.R.

Feibelman, P.J.
Surf. Sci. (1989) 216, 263-9 
44 Structure of platinum adatom clusters on $\mathrm{Pt}(100)$ : experimental observation and embeddedatom-methods calculations

45 Preparation technique of point-samples from $\mathrm{YBa}_{2} \mathrm{Cu}_{3} \mathrm{O}_{7 \cdot \mathrm{x}}$ monocrystals for investigation in field ion microscope

46 An FIM study on the initial stage of the surface reaction of tungsten with n-octanol under an applied DC voltage

47 Structural investigations on $\mathrm{Al}_{7}$ $\left(\mathrm{Mn}_{0.7} \mathrm{Fe}_{0.3}\right)_{2}$ and $\mathrm{Al}_{4} \mathrm{Pd}$ decagonal quasi crystals by FIM

48 FIM observation of $\mathrm{Fe}_{15} \mathrm{~N}_{2}$ in a nitrided pure iron

49 FIM observation of nitrogen GP zones in iron

50 The FCC to BCC transformation in Fe film on a spherical $\mathrm{Cu}$ substrate

51 Binding sites for cluster atoms: Ir on $\operatorname{Ir}(111)$

52 Imaging and diffusion of individual iridium adatoms on $\operatorname{Ir}(111)$

53 Cluster motion on metals: Ir on $\operatorname{Ir}(111)$
Schwoebel, P.R.

Foiles, S.M.

Bisson, C.L.

Kellogg, G.L.

Talantsev, E.F. Ivchenko, V.A.

Syutkin, N.N.

Pisma. Zh. T. (1989)

15, 76-9

Terao, $T$.

J. de Phys. (1989)

Iwatsu, F.

C8-50, 315-20

Phys. Rev. B (1989)

40, 639-42
Morikawa, $\mathrm{H}$.

van Bakel, G.P.E.M.

J. de Phys. (1989)

Bronsveld, P.M.

de Hosson, J.T.M.

Wada, M.

Fujii, A.

Komazaki, T.

Mori, T.

Wada, M.

Fujii, A.

Komazaki, T.

Mori, T.

Wada, M.

Uda, S.

Kato, M.

Wang, S.C.

Ehrlich, G.

Wang, S.C.

Ehrlich, G.

Wang, S.

Ehrlich, G.
Phil. Mag. A (1989)

59, 31-45

Surf. Sci. (1989) 217, L397-405

Surf. Sci. (1989) 224, L997-1003

High Nitrogen Steels (HNS 88) Proc. Intl. Conf., Lille, France, 1988, Fock, J. and Hendry, A., eds., Institute of Metals, London (1989), 143-6

Acta Metall. (1989) 37, 2349-55.$$
\text { L97-1003 }
$$

J. Chem. Phys. (1989) 91, 6535 
54 Self-adsorption sites on a

Wang, S.C.

Phys. Rev. Lett.

close-packed surface-Ir on $\operatorname{Ir}(111)$

Ehrlich, G.

(1989) 62, 2297-2300

55 Atomic jump lengths in surface-diffusion - Re, Mo, Ir, and $\mathrm{Rh}$ on W(211)

Wang, S.C.

Wrigley, J.D.

Ehrlich, G.

J. Chem. Phys. (1989)

91, 5087-96

56 Direct mapping of adatom-adatom interactions

Watanabe, F.

Phys. Rev. Lett.

Ehrlich, G.

(1989) 62, 1146-9

57 Field ion microscopy on clean and oxygen-etched W(111) tips

Wengelnik, $\mathrm{H}$.

Neddermeyer, $\mathrm{H}$.

Abstrast of 4th Intl.

Conf. on Scanning

Tunneling

Microscopy/

Spectroscopy STM

'89, 128, Oarai,

Ibaraki, Japan

58 Experimental verification of superconducting phase separation model in metallic glass $\mathrm{Zr}_{78} \mathrm{Co}_{22}$

Xianyi, Z.

Solid State

Zhiguo, $\mathbf{L}$.

Communication

et al.

(1989) 69, 981-6

59 Phase transformations at/near the

Yamamoto, M. surface of ordering alloys

Nenno, $\mathrm{S}$.

Surf. Sci. (1989) 213,

$502-24$ 
1 Silicon field emitter arrays: fabrication and operation

2 Frequency limits of electronic tubes with field emission cathodes

3 Temperature regime of graphite field-emission cathodes with large working surface

4 Factors influencing the stability of cold-cathodes formed by coating a planar electrode with a metal-insulator composite

5 Stimulated cold-cathode emission from metal electrodes coated with Langmuir-Blodgett multilayers

6 Low-field 'cold-cathode' electron emission from $\mathrm{Cu}$ electrodes overlayed by a resin-particle composite

7 Field emission fluctuations induced by the diffusion of atoms on a clean metal surface
Allen, P.C.

Anderson, W.A.

Astakhov, O.P. Makukha, V.I.

Sheshin, E.P.

Bajic, S.

Mousa, M.S.

Latham, R.V.

Bajic, $\mathbf{S}$.

Cade, N.A.

Archer, A.D.

Latham, R.V.

Bajic, S.

Latham, R.V.

J. de Phys. (1989)

C8-50, 79-84

Proc. 2nd Intl. Conf.

Vacuum

Microelectronics,

Turner, R.E., ed., 1989, 217-21, Institute of Physics, Bristol and NY

Radiotek. El. (1989)

34, 1310-2

Proc. 2nd Intl. Conf.

Vacuum

Microelectronics,

Turner, R.E., ed., 1989, 57-60, Institute of Physics, Bristol and NY

Proc. 2nd Intl. Conf.

Vacuum

Microelectronics, Turner, R.E., ed., 1989, 101-4, Institute of Physics, Bristol and NY

Bakhtizin, R.Z. J. de Phys. (1989)

Valeyev, V.G.

C8-50, 117-22 
8 Field emission current fluctuations from semiconductors: surface and bulk effects

9 Energetic characterization of field emission cathodes

10 Cross-correlation functions of the field emission fluctuations with slit probed regions

11 Improved adsorbate fluctuation measurements and their explanation by different diffusion mechanisms I. Arguments in favour of single adatoms surface diffusion

12 Improved adsorbate fluctuation measurements and their explanation by different diffusion mechanisms II. A plausible soliton mechanism

13 Surface diffusion of lithium on the $W(112)$ plane by field emission spectral density analysis

14 A field emission study of silicon

15 Transfer characteristics of carbon-fiber field-emission current
Bakhtizin, R.Z.

Baptist, R.

Ghis, A.

Meyer, $\mathbf{R}$.
Ghots, S.S.

J. de Phys. (1989)

C8-50, 103-8

Proc. 2nd Intl. Conf. Vacuum Microelectronics, Turner, R.E., ed., $1989,85-8$, Institute of Physics, Bristol and NY

Beben, J.

Kleint, $\mathrm{C}$.

Meclewski, $\mathbf{R}$.

J. de Phys. (1989)

C8-50, 97-102

Beben, J.

Kleint, C.

Surf. Sci. (1989) 213,

Meclewski, R.

Beben, J.

Kleint, C.

Pawe!ek, A.

Surf. Sci. (1989) 213, 451-63

Biernat, $\mathrm{T}$.

Kleint, $\mathrm{C}$.

J. de Phys. (1989)

C8-50, 123-8

Binh, V.T.

J. de Phys. (1989)

Chaouch, M.

C8-50, 443-9

Bondarenko, B.V. Radiotek. El. (1989)

Cherepanov, A.Y. $\quad$ 34, 1307-10

Shakhovskoy, A.G.

Sheshin, E.P. 
Field Emission Microscopy

16 Fluctuation phenomena in field Brodie, I. emission from molybdenum micropoints

17 Keynote address to the first international vacuum microelectronics conference, June 1988: pathways to vacuum microelectronics

18 Physical considerations in vacuum microelectronics devices

Brodie, I.

IEEE Trans. Electr. Devices (1989) $\underline{36}$, 2641-4

19 Lateral cold cathode triode structures fabricated on insulating substrates

Busta, H.H.

Busta, H.H. Shadduck, R.R. Orvis, W.J.

Proc. 2nd Intl. Conf. Vacuum Microelectronics, Turner, R.E., ed., 1989, 29-32, Institute of Physics, Bristol and NY

20 Field emission from tungsten-clad silicon pyramids

Cade, N.A.

21 Modeling of electron trajectories in field emission devices

22 Wet etching of cusp structures for field-emission devices

Cade, N.A.

Lee, R.A.

Patel, C.
IEEE Trans. Electr. Devices (1989) $\underline{36}$, 2679-85

Proc. 2nd Intl. Conf. Vacuum Microelectronics, Turner, R.E., ed., 1989, 109-12, Institute of Physics, Bristol and NY

IEEE Trans. Electr. Devices (1989) $\underline{36}$, 2709-14 
Field Emission Microscopy

23 Geometry optimization for a lateral triode

24 Alloy formation of $\mathrm{Ni}$ with reacting germane

25 Epitaxy of metals on metal substrates: the contribution of field electron emission microscopy

26 Fine-structure in field-emission resonances at surfaces

27 Tunneling theory and vacuum microelectronics

28 Field emission gun for microengineering application

29 Focused electron-emission from planar quantum point contacts

30 Nanolithography using field emission and conventional thermionic electron sources

31 A creation of grain boundaries by an electric field
Carr, W.N.

Wang, H.J.

Chin, K.K.

Marcus, R.B.

Ciszewski, A.

Frank, $O$.

Block, J.H.

Ciszewski, A.

Melmed, A.J.

Coombs, J.H.

Gimzewski, J.K.

Cutler, P.H.

Feuchtwang, T.E.

Huang, $Z$.

Sullivan, $T$.

Delong, A

Kolarik, V.

Deraedt, $\mathrm{H}$.

Garcia, N.

Saenz, J.J.

Devenish, R.W.

Eaglesham, D.J.

Maher, D.M.

Humphreys, C.J.

Drechsler, $\mathrm{M}$.

Neddermeyer, $\mathrm{H}$.
Prog. Surf. Sci. (1989)

32, 173-210

J. Microsc. (1989)

152, 841-51

Proc. 2nd Intl. Conf.

Vacuum

Microelectronics, Turner, R.E., ed., 1989, 195-9, Institute of Physics, Bristol and NY

Surf. Sci. (1989) 213, 316-20

Proc. 2nd Intl. Conf.

Vacuum

Microelectronics, Turner, R.E., ed., 1989, 121-32, Institute of Physics, Bristol and NY

J. Phys. E: Sci.

Instrum. (1989) 22, 612-4

Phys. Rev. Lett. (1989) 63, 2260-3

Ultramicroscopy

(1989) 로, 324-9

Surf. Sci. (1989) 209, 
32 Effect of thin silicon films on field emission from molybdenum and tantalum cathodes

33 Comparison of vacuum and semiconductor field effect transistor performance limits

34 Analysis of particle trajectories on an interactive desktop system

35 Study of the thermal field ion emission from metalsemiconductor system

36 Interface phenomena in the field ion and field electron energy spectroscopy of high- $T_{c}$ superconductors

37 A mathematical model to predict optimum geometry of the elements of a field emitter array cathode

38 Monte Carlo calculation and vacuum emission experiments of hot and ballistic electrons from MIS-structures
Duann, J.

Eastman, L.F.

Edgcombe, C.J. Roberts, D.E.

Egorov, N.V.

Korol'kov, A.E.

Ernst, N.

Bozdech, G.

Schmidt, W.A.

Naschitzki, M.

Melmed, A.J.

Feeney, R.K.

Cochran, J.K.

Hill, D.D.

Chapman, A.T.

Fitting, H-J.
(1989) 85, Univ. Microfilms Int., Order No. DA8916999

Proc. 2nd Inil. Conf. Vacuum Microelectronics, Turner, R.E., ed., 1989, 189-94, Institute of Physics, Bristol and NY

Proc. 2nd Intl. Conf. Vacuum Microelectronics, Turner, R.E., ed., 1989, 181-4, Institute of Physics, Bristol and NY

Zh. Tekh. Fiz. (1989)

59, 129-31

J. de Phys. (1989)

C8-50, 471-5

Proc. 2nd Intl. Conf. Vacuum Microelectronics, Turner, R.E., ed., 1989, 117-20, Institute of Physics, Bristol and NY

Proc. 2nd Intl. Conf. Vacuum Microelectronics, Turner, R.E., ed., 1989, 133-6, Institute of Physics, Bristol and NY 
Field Emission Microscopy

39 Electron emission from small sources

40 Simulation of the processes in semiconductor surface space-charge region under field-emission conditions

41 Thermal-field-emission electron optics for nanolithography

42 Effect of magnetic quantization on field emission from quaternary alloys

43 Surface self-diffusion and thermal roughening study of tungsten single crystal planes by field emission fluctuation method

44 Field emitter arrays-more than a scientific curiosity?

45 An experimental study of the physics of field emission by tip arrays

46 Secondary-electron-field emission for capture site spectroscopy in thin insulator layers

47 Electrical characterization of gridded field emission cathodes
Garcia, N.

Saenz, J.J.

de Raedt, $\mathrm{H}$.

J. Phys.: Condens.

Matter (1989) 1 ,

9931-56

Germ, V.E.

Mileshkina, N.V.

Radiotek El (1989)

Semykina, E.A.

Gesley, M.

J. Appl. Phys. (1989)

$65,914-26$

Ghatak, K.P.

Fizika (Zagreb)

(1989) 21, 17-24

Gong, Y.

Zhenkong Kexue Yu

Jishu (1989) 9, 179-84

Gray, H.F.

J. de Phys. (1989)

C8-50, 67-72

Harvey, R.J.

Lee, R.A.

Miller, A.J.

Wigmore, J.K.

Hecht, D.

Fitting, H.J.

Howell, D.F.

Groves, R.D.

Lee, R.A.

Patel, C.

Williams, H.A.
Proc. 2nd Intl. Corif.

Vacuum

Microelectronics,

Turner, R.E., ed., 1989, 113-6, Institute of Physics, Bristol and NY

Phys.

Halbleiteroberflaeche (1989) 20, 81-4

Proc. 2nd Intl. Conf.

Vacuum

Microelectronics,

Turner, R.E., ed., 1989, 81-4, Institute of Physics, Bristol and NY 
Field Emission Microscopy

48 Computer simulation of a wave packet tunneling through a square barrier

49 Theoretical study of a vacuum field effect transistor

50 Field-emission propertics of surface-processed $\mathrm{TiC}$ tips

51 Emitters in electric fieldionization type ion gas sources in semiconductor device manufacture

52 Fabrication and theoretical study of micron-size vertical vacuum triodes

53 Changes in the field-emitted electron-energy spectra induced by cerium adsorption on $\mathrm{W}$

54 Fabrication of sharp field emission structures using ion beam milling
Huang, Z-H. Cutler, P.H.

Feuchtwang, T.E.

Good, R.H., Jr.

Kazes, E.

Nguyen, H.Q.

Park, S.K.

Huang, Z-H. Cutler, P.H.

Feuchtwang, T.E. Gray, H.F.

Ishizawa, Y.

Aoki, S.

Oshima, C.

Otani, S.

Itakura, $\mathrm{T}$.

Itoh, J.

Hiroshima, $\mathrm{H}$.

Ivanov, V.A.

Kirsanova. T.S.

Tumarova, T.A.

Jacobson, S.E.

Cade, N.A.

Lee, R.A.
IEEE Trans. Electr. Devices (1989) 36, 2665-70

Proc. 2nd Intl. Conf. Vacuum Microelectronics, Turner, R.E., ed., 1989, 223-6, Institute of Physics, Bristol and NY

J. Phys. D: Appl. Phys. (1989) 22, 1763-67

Jpn. Kokai Tokkyo Koho (1989), 4

Proc. 2nd Intl. Conf. Vacuum Microelectronics, Turner, R.E., ed., 1989, 231-4, Institute of Physics, Bristol and NY

Fizika Tverdogo Tela (1989) $\underline{31}, 82-5$

Proc. 2nd Intl. Conf. Vacuum Microelectronics, Turner, R.E., ed., 1989, 5-8, Institute of Physics, Bristol and NY 
Field Emission Microscopy

55 Effect of gases on emission characteristics of the tantalum

Jiang, $X$.

Zhenkong Kexue Yu Jishu (1989) 9, 153-9

Khairnar R.S.

Univ. Poena (1989)

Thesis, Pune, India

$\mathrm{LaB}_{6} / \mathrm{W}$, metallic glass and graphite composite

57 Study of direct-current, pulsed, and temperature-field emission from $\mathrm{LaB}_{6}$ /tungsten fielả emitter

58 Metallic glass as a field electron emitter

59 Pencil lead field emitter

60 Metal-serniconductor (Si,GaAs) interfaces

61 Effect of preadsorbed nirkel atoms upon the potassium mobility on the $\mathrm{W}(112)$ plane

62 FEM and FIM study of metal-support interaction

63 New application of field emission techniques (FEM and FIM) to the study of catalytic systems

64 An x-ray projection microscope with field emission gun

65 A wide-bandwidth high-gain smail-size distributed amplifier with field-emission uriodes (FETRODE's) for the 10 to $300 \mathrm{GHz}$ frequency range
Khairnar, R.S.

Dharmadhikari, C.V.

Joag, D.S.

Kanitkar, P.L.

Nigavekar, A.S.

Khairnar, R.S.

Joag, D.S.

J. Phys. D: Appl.

Phys. (1989) 22, 547-9

Khairnar, R.S.

Joag, D.S.

J. de Phys. (1989)

C8-50, 85-90

Kim, $\mathbf{H}$.

Hashio, F.

J. de Phys. (1989)

Sakurai, T.

Kleini, C.

Blaszczyszyn, R.

J. de Phys. (1989)

C8.50, 91-6

Knor, Z.

Sotola, J.

Surf. Sci. (1989) 213, 371-80

Knor, Z.

Sotola, J.

Revue Roumaine de Chimie (1989) 34, 1373-6

Kolarik, V.

Svoboda, V.

J. Microsc. (1989)

$156,247.51$

Kosmahl, H.G.

IEEE Trans. Electr. Devices (1989) $\underline{36}$, 2728-37 
Field Emission Microscopy

66 An x-band tuned amplifier with a field-emission cathode

67 Field-enhanced emission

68 Characterization of individual micro-emission centres distributed in planar array:

69 Thermal relaxation of a laser illuminated field emitter

70 Construction and performance of field emitting cathodes
Laliy, P.M.

Goren, Y.

Nettesheim, E.A.

Landsberg, P.T.
Latham, R.V. Archer, A.D.
Lee, M.J.G.

Rubins, E.S.

Lee, R.A.

Miller, A.J.

Patel, C.

Williams, H.A

Lee, R.A.

Patel, C.

Williams, H.A.

Cade, N.A.

Li, X.Q.D.

Vanselow, R.

stepped/kinked surface areas of a rounded Pt crystal I. Clean

surface

73 Dissociation of $\mathrm{CO}$ on stepped/kinked surface areas of a rounded Pt crystal II. Influence of low Si contamination
Li, X.Q.D. Vanselow, R.
IEEE Trans. Electr. Devices (1989) $\underline{36}$, 2738-41

Proc. 2nd Intl. Conf, Vacuum Microelectronics, Turner, R.E., ed., 1989, 149-52, Institute of Physics, Bristol and NY

Proc. 2nd Intl. Conf. Vacuum Microelectronics, Turner, R.E., ed., 1989, 153-64, Institute of Physics, Bristol and NY

J. Appl. Phys. (1989) $65,1699-706$

Proc. 2nd Intl. Conf. Vacuum Microelectronics, Turner, R.E., ed., 1989, 105-8, Institute of Physics, Bristol and NY

IEEE Trans. Electr. Devices (1989) $\underline{36}$, 2703-8

Catalysis Lett. (1989) 2, 113-20

Surf. Sci. (1989) 217,

\section{L417-22}


74 Dissociation of $\mathrm{CO}$ on rounded Pt crystals III. Influence of high Si contamination on the dissociation activity of $\{210\}$ and $\{1195\}$ areas

75 A general formula to calculate the field intersity on the field emitter

76 Preparation and characterization of zirconium carbide field emitters

77 Ballistic field emission devices

78 Simulation and design of field emitters
Li, X.Q.D.

Vanselow, R.

Surf. Sci. (1989) 217,
Luo, E. Lin, $Y$. Huang, W.

Mackie, W.A. Hinrichs, C.H. Davis, P.R.
Makhov, V.I.

Proc. 2nd Intl. Conf. Vacuum

Microelectronics, Turner, R.E., ed., 1989, 95-9, Institute of Physics, Bristol and NY

IEEE Trans. Electr. Devices (1989) 36, 2697-702

Proc. 2nd Intl. Conf. Vacuum Microelectronics, Turner, R.E., ed., 1989, 235-8, Institute of Physics, Bristol and NY
Marcus, R.B.

Chin, K.K.

Yuan, Y.

Wang, H.J.

Carr, W.N.

Proc. 2nd Intl. Conf. Vacuum Microelectronics, Turner, R.E., ed., 1989, 77-80, Institute of Physics, Bristol and NY

Maslov, V.I. J. de Phys. (1989) Fursey, G.N. Kocheryshenkov, A.V. elementary acts of field emission with time resolution of $5 \mu \mathrm{s}$ 100 ps

80 Statistics of field emission from tungsten over a wide range of current densities

Maslov, V.I. Fursey, G.N. Zh. Tekh. Fiz. (1989) Kocheryshenkov, A.V.
59, 164-7 
81 An STM controlled field emission microlens electron source

82 Gigatron

83 A simplified analysis of the field emission from semiconductor superlattices under magnetic quantization

84 A high-voltage pulse source for electron-beam generation using field-emission

85 Field emission gun for surface studies

86 Application of a scanning tunneling microscope to field emission studies

87 Investigation of field emitting microstructures by scanning electron and scanning tunnelling microscopy
McCord, M.A. Chang, T.H.P. Kern, D.P. Speidell, J.L.

McIntyre, P.M. Bizek, H.M. Elliott, S.M. Nassiri, A. Popovic, M.B. Raparia, D. Swenson, C.A. Gray, H.F.

Mitra, B.

Ghatak, K.P.

Mizuno, A.

Kamase, $Y$.

Morin, P.

Ning, L.H.

l'ellerin, $\mathrm{F}$.

Niedermann, $P$. Fischer, O.

Niedermann, $\mathbf{P}$. Reneer, C. Kent, A.D. Fischer, $\mathrm{O}$.
Proc. 2nd Intl. Conf. Vacuum Microelectronics, Turner, R.E., ed., 1989, 165-6, Institute of Physics, Bristol and NY

IEEE Trans. Electr. Devices (1989) $\underline{36}$, 2720-7

Phys. Lett. A (1989) 142, 401-4

IEEE Ind. Ap. (1989) $25,54-61$

Ultramicroscopy (1989) 르, 103-7

IEEE Trans. Electr. Insul. (1989) 24, 905-10

Proc. 2nd Intl. Conf.

Vacuum Microelectronics, Turner, R.E., ed., 1989, 173-6, Institute of Physics, Bristol and NY 
Field Emission Microscopy

88 Micro-cavity integrable vacuum devices and triodes

Orvis, W.J.

McConaghy, C.F.

Proc. 2nd Intl. Conf.

Ciarlo, D.R.

Vacuum

Yee, J.H.

Hee, E.W.

Microelectronics, Turner, R.E., ed., 1989, 207-10, Institute of Physics, Bristol and NY

89 Modeling and fabricating micro-cavity integrated vacuum tubes

Orvis, W.J.

McConaghy, C.F. Ciarlo, D.R.

Yee, J.H.

Hee, E.W.

90 Survey of electron sources for high-resolution microscopy

Orloff, J.

Ultramicroscepy (1989) 28, 88-97

Phillips, P.M. Smith, S.T.

Gray, H.F.

Proc. 2nd Intl. Conf.

Vacuum

Microelectronics, Turner, R.E., ed., 1989, 211-6, Institute of Physics, Bristol and NY

Renner, C. IEEE Trans. Electr.

92 Enhanced field emission investigation of aluminum

93 Electron emission from small microtips

Niedermann, P. Insul. (1989) 24,

Fischer, $O$. 911-6

Saenz, J.J. J. de Phys. (1989)

Garcia, N. $\quad$ C8-50, 73-8

de Raedt, $\mathrm{H}$.

Binh, V.T.

Schwab, U.

OPTIK (1989) $\underline{81}$, 109-12 glassy-carbon

95 Adsorption of heavy rare-earth atoms on (011) and (111)W

96 Emitter and electron-gun

Shakirova, S.A.

Shevchenko, M.A.

J. de Phys. (1989)

C8-50, 129-34

Shimoyama, $\mathrm{H}$.

J. Elec. Microsc.

Ichihashi, M.

(1989) 38, S1-9

Tamura, N. 
97 Influence of condensed gases on field-emission and the performance of superconducting RF cavities

98 Self-aligned silicon-strip field emitter array

99 Fabrication of densely packed, sharp, silicon field emitters using dry etching

100 Metallic glass field emission spectra

101 Investigation of self-diffusion on tungsten by field emission microscopy

102 Nature of photosensitivity of semiconductor field-emission

103 Low-energy electron projection microscopy

104 Total energy distribution of field-emitted electrons from polyacrylonitrile-based high-modulus carbon fibres
Shu, Q.S.

Gandreau, $\mathrm{K}$.

Hartung, W.

Kirchges, J.

Moffat, D.

Noeu, $R$.

Padamsee, $\mathrm{H}$.

Rubin, D.L.

Sears, J.

Spallas, J.P.

Arney, S.C.

Cheng, C.C.

MacDonald, N.C.

Stephani, D.

Eibl, J.

Proc. 2nd Intl. Conf.

Vacuum

Microelectronics,

Turner, R.E., ed., 1989, 1-4, Institute of Physics, Bristol and NY

Proc. 2nd Intl. Conf. Vacuum

Microelectronics, Turner, R.E., ed., 1989, 9-12, Institute of Physics, Bristol and NY

Stepien, Z.M. Kukulka, J.

Stetsenk, B.V.

Stocker, W. Fink, H-W. Morin, R.

Tagawa, M. Nishida, $\mathrm{S}$. Ohmae, $\mathrm{N}$. Phil. Mag. (1989)
Stepien, Z.M.

Pisma Zh. T. (1989) $15,22-4$

J. de Phys. (1989)

C8-50, 519-22 B59, 279-86

J. de Phys. (1989)

C8-50, 109-12

Surf. Sci. (1989) 216, 505-8

Umeno, $\mathrm{M}$. 
105 Improvement of beam characteristics by superimposing a magnetic-field on a field-emission gun

$106 \mathrm{~A}$ high throughput electron lithography system using a field emission gun

107 Present and future of electron holography

108 Magnetic field emission gun with zirconiated emitter

109 Magnetic field emission gun with zirconiated emitter:

performances at low voltage

110 New field emission gun with energy filtering effect

111 Electron sources: Summary

112 Emission characteristics of a hafniated oriented tungsten thermal field emission source

113 The dynamics and stability of solid surfaces of nanostructures
Takaoka, A.

Ura, $K$.

Tomita, $\mathrm{T}$.

Harada, Y.

Thompson, W.B. Electron-Beam, Nakagawa, $Y$. Shearer, $Y$. Hassel, M.

Nakazawa, $\mathrm{H}$.

Takemura, $\mathrm{H}$. Isabe, $\mathbf{M}$.

Gato, N.

Tonomura, A.

Troyon, $\mathbf{M}$.

Troyon, M.

Troyon, $\mathrm{M}$.

Troyon, $\mathrm{M}$.

Troyon, M. Pandey, A.K. Orlikowski, J.P.

Tsong, T.T. Chen, $\mathrm{C}$.
J. Elec. Microsc.

(1989) 38, 83-94

X-Ray, Ion-Beam

Technol.:

Submicrometer

Lithogr. 8 (1989)

Proc. SPIE-Int. Soc.

Opt. Eng., 260-7

J. Elec. Microsc. (1989) 38, 43-50

J. Elec. Microsc. Tech. (1989) 11, 191-5

Ultramicroscopy (1989) 로, 98-102

J. Appl. Phys. (1989) 66, 1-4

Ultramicroscopy (1989) 르, 207-8

J. Vac. Sci. Technol., (1989) A7, 3112-6

Proc. 2nd Intl. Conf. Vacuum Microelectronics, Turner, R.E., ed., 1989, 167-72, Institute of Physics, Bristol and NY 
114 Field electron spectroscopy of barium oxide films of various structures

115 Two-dimensional graphite $\{0001\}$ island on $\mathrm{Pt}\{110\}$ and its vicinal areas: nucleation, growth mechanism and epitaxial orientation

116 Control of silicon field emitter shape with isotropically etched oxide masks

117 Work function measurements of $\left(\mathrm{W}-\mathrm{Sc}_{2} \mathrm{~W}_{3} \mathrm{O}_{12}\right.$ )-coated impregnated cathode by retarding potential method utilizing titaniated W(100) field emitter
Tumareva, T.A. Ivanov, V.A. Kirsanova, T.S. Vasilyeva, N.V.

Vanselow, $R$. Braun, $M$. van der Merwe, J.H.

Surf. Sci. (1989) 214 , 197-208

Warren, J.B.

Proc. 2nd Intl. Conf. Vacuum Microelectronics, Turner, R.E., ed., $1989,37-40$, Institute of Physics, Bristol and NY

Yamamoto, S. Yaguchi, $\mathrm{T}$. Sasaki, S.

Watanabe, I.
Jpn. J. Appl. Phys. (1989) 28, L865-7 
Liquid Metal Ion Sources

1 Development of focused ion beam systems

Aihara, R. Sawaragi, $H$.

Nucl. Instrum.

Thompson, B.

Shearer, M.H. Methods Phys. Res. (1989) B37/38, 212-7

2 The emittance characteristics of a

Alton, G.D. gallium liquid-metal ion source

Read, P.M.

J. Appl. Phys. (1989)

66, 1018-22

3 The emittances of ${ }^{69} \mathrm{Ga}^{+}$ion beams extracted from a

Alton, G.D.

J. Phys. D: Appl. liquid-metal ion source

Read, P.M.

Phys. (1989) 22,

1029-37

4 Emission characteristics of liquid metal ion source

Arimoto, $\mathrm{H}$.

J. de Phys. (1989)

Komura, $M$.

C8-50, $165-70$

5 Finely-dispersed phases and instability of the emission of liquid-metal ion sources

Badan, V.E.

Gasanov, I.S.

Pisma Zh. T. (1989)

$15,49-52$

Barr, D.L.

Brown, W.L.

J. Vac. Sci. Technol. liquid metal ion source as observed with an ion streak camera

7 Lithium ion emission from a liquid metal ion source of lithium nitrate

Bell, A.E.

Int. J. Mass. Spectrum

Schwind, G.A.

Rao, $\mathrm{S}$.

Ion Phys. (1989) 요,

Swanson, L.W. 59-68

8 Vacuum arc liquid-metal ion source

Bernardet, $\mathrm{H}$.

Pauwe, J.C.

Fr. Demande (1989), 14

Burmii, Z.P.

Vysokochist.

9 Basic energy characteristics of the electron current of a liquid metal ion source

Sikharulidze, G.G.

Veshchestba (1989) 2, 193-8

Chen, G.

Ishikawa, J.

Hejishu (1989) 12,

Takagi, $\mathrm{T}$.

85-8

Chung, M.S.

Cutler, P.H.

J. Appl. Phys (1989)

Miskovsky, N.M.

66, 6065-71 treatment of the shape and instability of liquid metal ion sources

12 Manipulating the micron

Clampitt, R.

Physics World (1989)

2, 66 


\section{Liquid Metal Ion Sources}

13 Modeling of liquid-metal ion sources

14 Microfocused ion-beam applications in microelectronics

15 Focused ion-beam secondary ion mass-spectrometry - ion images and endpoint detection

16 A unified description of liquid metal ion source energy distributions

17 The emission characteristics of an indium needle-type liquid metal ion source

18 The high-temperature behavior of gallium and indium liquid metal ion sources

19 The effects of source temperature and characteristics on the optical emission from a gallium liquid metal ion source

20 The properties of high-intensity impregnated-electrode-type liquid-metal ion sources

21 Direct deposition of focused ion beams with an impregnatedelectrode-type liquid metal ion source

22 Intense metal ion beam formation by an impregnated-electrode-type liquid metal ion source

23 Observation of doubly-charged dimer ion emission in liquid-metal-ion sources
Forbes, R.G.

Ljepojevic, N.N.

Vac. (1989) $\underline{39}$,

Harriott, L.R.

Appl. Surf. Sci. (1989) $\underline{36}, 432-42$

Harriott, L.R. Vasile, M.J.

J. Vac. Sci. Technol. (1989) B7, 181-7

Hornsey, R. I. J. de Phys. (1989) C8-50, 197-202

Hornsey, R.I. Appl. Phys. A (1989) 49, 293-7

Hornsey, R.I. Appl. Phys. A (1989) 49, 697-705

Hornsey, R.I. Marriott, $\mathrm{P}$.

J. Phys. D: Appl. Phys. (1989) 22, 699-704

Ishikawa, J.

Nucl. Instrum. Methods Phys. Res. (1989) B40-41, 1037-41

Ishil awa, J. Tsuji, H.

Nucl. Instrum. Methods Phys. Res. (1989) B37-38, 151-4

Kashiwagi, T.

Aoyama, Y.

Takagi, $T$.

Ishikawa, J.

Tsuji, $\mathrm{H}$.

Kashiwagi, T.

Takagi, $\mathrm{T}$.

Ishitani, $\mathrm{T}$.

Umemura, $\mathrm{K}$.

Kawanami, Y.
Nucl. Instrum.

Methods Phys. Res. (1989) B37-38, 155-8

Surf. Sci. (1989) 218, 259-68 
24 Development of liquid-metal-ion sources for focused-ion beam applications

25 Focused ion beam technologies for lithographic applications

26 Field emission of liquid metals in alternating fields

27 SIMs depth profiling of $\mathrm{Si} / \mathrm{SiO}_{2} / \mathrm{Si}$ layers by using self-sputtered $\mathrm{Ga}+$ from a gallium liquid-metal ion-source

28 Mass spectra of Au-Ge alloy liquid metal ion sources

29 Focused phosphorus ion beam implantation into silicon

30 Instabilities in liquid metal ion emitters

31 On the onset voltage of liquid-metal ion sources

32 Ions field-emitted from a liquid-gallium-filled capillary

33 A hydrodynamical study of the instability of a planar liquid metal ion sources (summary)

34 A scanning ion microbeam system with a liquid-metal ion-source
Ishitani, $\mathbf{T}$.

Umemura, $\mathrm{K}$.

Kawanami, Y.

Ohnishi, T.

Kato, T.

Yasuoka, A.

Fujikawa, K.

J. Electrochem. Soc. (1989) 136, 3502-5

Nucl. Instrum.

Methods Phys. Res. (1989) B37/38, 218-23

Kontonistov, A.A.

Radchenko, I.N.

Fursey, G.N.

J. de Phys. (1989)

C8-50, 203-10

Shirochin, L.A.

Licciardello, A.

Torrisi, A.

Pignataro, S.

Surf. Sci. (1989) $\underline{14}$, 491-5

Machalett, F.

Muhle, R:

Stiebritz, I.

Gotz, G.

Madokoro, Y.

Shukur, S.

Umemura, $\mathrm{K}$.

Tamura, $\mathrm{M}$.

Mair, G.L.R.

J. de Phys. (1989)

C8-50, 171-4

Mair, G.L.R.

Nucl. Instrum.

Methods, Phys. Res.

(1989) B43, 240-2

Mair, G.L.R.

Thoms, S.

J. Phys. D: Appl.

Phys. (1989) 22, 975-6

Miskovsky, N.M. J. de Phys. (1989)

He, P.

C8-50, 175-8

Cutler, P.H.

Chung, $M$.

Mittenbacher, J. Muhle, R.
Phys. Status Solidi A (1989) 112, 825-8 


\section{Liquid Metal Ion Sources}

35 Emission performance of a slit type caesium field ion source

36 Miniaturized liquid metal field electron and ion sources

37 Ion species and energy control of finely focused FIBs for maskless in situ microfabrication processes

38 Focused ion beam processing

39 Formation of microclusters by the electrohydrodynamic ion source method from liquid metal

40 Generation of pure gallium ion beams by field ionization of laser-excited Rydberg atoms

41 Focused ion beams in microfabrication

42 A theoretical and experimental study of liquid metal ion sources and their application to focused ion beam technology

43 A combination electron/ion field emission source

44 Angular distribution and energy spread measurements on $\mathrm{Ga}$ clusters emitted from an isotopically pure liquid metal ion source
Mitterauer, J.

J. de Phys. (1989)

C8-50, 191-6

Mitterauer, J.

Miyauchi, E. Arimoto, $\mathrm{H}$. Kitada, $\mathrm{H}$.

Namba, S.

Noda, $T$. Saito, Y.

Domori, T.

Ono, $\mathrm{K}$.

Murai, Y.

Proc. 2nd Intl. Conf.

Vacuum

Microelectronics, Turner, R.E., ed., 1989, 61-4, Institute of Physics, Bristol and NY

Nucl. Instrum.

Methods Phys. Res. (1989) B39, 515-20

Nucl. Instrum.

Methods Phys. Res. (1989) B39, 504-10

Nippon Butsuri Gakkaiski (1989) 444, 234-6

Prewett, P.D.

Nucl. Instrum. Methods Phys. Res. (1989) B37/38, 124-7

J. de Phys. (1989) C8-50, 179-90

Puretz, J. (1989) 269, Univ. Microfilms Int., Order No. DA8919368

Rao, K.A. Bell, A.E.

Schwind, G.A. J. Vac. Sci. Technol. (1989) B7, 1793-7

Swanson, L.W.

Rao, S.

J. Vac. Sci. Technol.

Bell, A.E.

Schwind, G.A. (1989) B7, 1787-92 
45 Abundance of Na cluster ions ejected from a liquid-metal ion-source

46 Cluster cations ejected from liquid metal ion source: alkali metals $(\mathrm{Li}, \mathrm{Na})$ and group IV elements ( $\mathrm{Si}, \mathrm{Ge}, \mathrm{Sn}, \mathrm{Pb}$ )

47 Liquid metal ion sources

48 Development of an arsenic liquid-metal ion source

49 Role of fragmentation processes in the liquid metal ion source production of aggregates

50 Focused ion beam repair of lithographic masks

51 Dynamical characteristics of liquid metal ion sources
Saito, Y. Minami, $\mathbf{K}$. Ishida, $\mathrm{T}$. Noda, $T$.

Saito, Y. Noda, $T$.

Swanson, L.W. Bell, A.E.

Umemura, $\mathrm{K}$. Kawanami, Y. Ishitani, $T$.

van de Walle, J. Joyes, $\mathbf{P}$.

Wagner, A. Levin, J.P.

Zheng, C. Linsu, $\mathrm{T}$.
Z. Phys. D, Atoms, Molecules and Clusters (1989) 11, 87-91

Z. Phys. D, Atoms, Molecules and Clusters (1989) 12 , 225-7

Phys. Technol. Ion Sources (1989), 313-30

Nucl. Instrum. Methods Phys. Res. (1989) B37-38, 208-11

Z. Phys. D, Atoms, Molecules and Clusters (1989) 12 , 221-4

Nucl. Instrum. Methods Phys. Res. (1989) B37/38, 224-30

J. Vac. Sci. Technol. (1989) B7, 1813-5 
Scanning Tunneling Microscopy

1 A new microtip for STM

Akama, Y.

J. de Phys. (1989)

Nishimura, E.

C8-50, 211-6

Sakai, A.

Sano, N.

Sakurai, $\mathrm{T}$.

2 Spin-polarized secondary

Allenspach, R.

Appl. Phys. Lett.

electrons from a scanning

tunneling microscope in field

Bischof, A.

(1989) 느, 587-9

emission mode

3 Electron-optical performance of a scanning tunneling microscope controlled field-emission microlens system

4 A simple new technique for preparing STM tips

5 A measurement of a surface self-diffusion coefficient by scanning tunneling microscopy

6 Direct tip structures determination by scanning tunneling microscopy

7 Imaging of metal-coated biological samples by scanning tunneling microscopy

Chang, T.H.P.

J. Vac. Sci. Technol.

Kern, D.P.

McCord, M.A. (1989) B7, 1855-61

Chen, Y.

$\mathrm{Xu}, \mathrm{W}$.

Huang, J.

J. "nys. E: Sci.

Instrum. (1989) 22,

455-7

Drechsler, M.

J. de Phys. (1989)

Blackford, B.L. $\quad$ C8-50, 223-8

Putnam, A.M.

Jericho, M.H.

Garcia, R.

Huerta, M.A.G.

J. de Phys. (1989)

C8-50, 235-42

Garcia, R.

Ultramicroscopy

Keller, D.

(1989) 27, 367-73

Panitz, J.

Bear, D.G.

Bustamante, C.

8 Fabrication and characterization of microtips for insitu scanning tunneling microscopy

Gewirth, A.A.

J. Elec. Chem. (1989)

Craston, D.H.

261, 477-82

Bard, A.J.

9 New fields for STMs

Gimzewski, J.

Phys. World (1989) 2, 25-8 
Scanning Tunneling Microscopy

10 Scanning tunneling microscopy study of alkali metal adsorption on the $\mathrm{Si}(001) 2 \times 1$ surface

11 Field ion-scanning tunneling microscopy investigation of alkali metal $(\mathrm{Li}, \mathrm{K})$ adsorption on $\mathrm{Si}$ surfaces

Hasegawa, $Y$. Hashizume, $\mathrm{T}$. Kamiya, I. Ide, $T$.

Sumita, I.

Tochihara, $\mathrm{H}$.

Kubota, M.

Murata, Y.

Hashizume, T.

Hashizume, T. Kamiya, I.

Hasegawa, Y.

Sumita, i.

Hyodo, S.

Sakurai, T.

Tanaka, $\mathrm{K}$.

Hirano, $\mathrm{H}$.

Yamada, T.

Hashizume, T. Kamiya, I.

Hasegawa, Y.

Ide, $\mathrm{T}$.

Pickering, H.W.

Sakurai, T.
J. de Phys. (1989)

C8-50, 229-34

\begin{abstract}
Intl. Conf. on Scanning Tunneling Microscopy/ Spectroscopy STM '89, Oarai, Ibaraki, Japan
\end{abstract}

Abstracts 4th Intl. Conf. on Scanning Tunneling Microscopy/ Spectroscopy STM '89, Oarai, Ibaraki, Japan

Characterization of the Structure and Chemistry of Defects in Materials, Mat. Res. Soc. Symp. Proc. (1989) 139, 297-302, Krakow, W., Ponce, F.A., and Smith, D.J., eds., MRS, Pittsburgh, PA 
14 Construction of R.T. FI-STMs and its applications

15 Mineralogy in two dimensions: scanning tunneling microscopy of semiconducting minerals with implications for geochemical reactivity

16 Model studies of tunneling time

$17 " 2 \times 8^{\prime \prime}$ phase of the $\operatorname{Si}(100)$ surface studied by the FI-STM

18 Development of the field ion-scanning tunneling microscope and its applications

19 A novel scanning tunneling microscope controlled fieldemission microlens electron source
Hashizume, T. Hasegawa, Y. J. de Phys. (1989)

Kamiya, I. C8-50, 513-8

Sano, N.

Kakoyama, $\mathrm{K}$.

Tanaka, $\mathrm{H}$.

Sumita, I.

Takao, M.

Hyodo, S.

Sakurai, T.

Hochella, M.F., Jr. Am. Mineral (1989)

Eggleston, C.M. $\quad$ 74, 1233-46

Elings, V.B.

Parks, G.A.

Brown, G.E., Jr.

Wu, C.M.

Kjoller, K.

Huang, Z.H.

Cutler, P.H.

Feuchtwang, T.E.

Kazes, E.

Nguyen, H.Q.

Sullivan, T.E.

Kamiya, I.

Hashizume, $\mathrm{T}$.

Hasegawa, Y.

Sumita, I.

Hyodo, S.

Pickering, H.W.

Sakurai, T.

Tochihara, $\mathrm{H}$.

Kubota, M.

Muratoa, Y.

Kamiya, I.

Sakurai, T.

J. de Phys. (1989)

C8-50, 491-6

\begin{abstract}
Intl.
Conf. on Scanning

Tunneling

Microscopy/

Spectroscopy STM '89, Oarai, Ibaraki, Japan
\end{abstract}

Abstracts 4th Intl. Conf. on Scanning Tunneling Microscopy/ Spectroscopy STM '89, Oarai, Ibaraki, Japan

McCord, M.A. Chang, T.H.P. J. Vac. Sci. Technol. Kern, D.P. (1989) B7, 1851-4 
20 Mechanisms of current rectification in an STM tunnel junction and the measurement of an operational tunneling time

21 Study of field emitting microstructures using a scanning tunneling microscope

22 Correlation between STM/STS images and apex profiles of scanning tips

23 Image quality of STM and apex profile of a scanning tip

24 Electron emission from small sources
Nguyen, H.Q.

Cutler, P.H

IEEE Trans. Electr.

Feuchtwang, T.E.

Huang, Z-H.

Kuk, Y.

Silverman, P.J.

Lucas, A.A.

Sullivan, T.E.

Niedermann, $\mathrm{P}$.

Renner, C.

Kent, A.D.

Fischer, $\mathrm{O}$.

Nishikawa, $\mathrm{O}$. Tomitori, $\mathrm{M}$.

Iwawaki, $\mathrm{F}$.

Hirano, N.

Nishikawa, O.

Tomitori, M.

Iwawaki, F.

Katsuki, F.

Saenz, J.J.

Garcia, N.

de Raedt, $H$.
Devices (1989) 36,

2671-8

Abstracts $\Delta$ th Intl.

Conf. on Scanning

Tunneling

Microscopy/

Spectroscopy STM

'89, Oarai, Ibaraki,

Japan

Abstracts 4th Intl.

Conf. on Scanning

Tunneling

Microscopy/

Speciroscopy STM

'89, Oarai, Ibaraki,

Japan

J. de Phys. (1989)

C8-50, 217-22

Abstracts 4th Intl.

Conf. on Scanning

Tunneling

Microscopy/

Spectroscopy STM

'89, Oarai, Ibaraki,

Japan 
25 FI-STM investigation of hydrogen chemisorption on the $\operatorname{Si}(111) 7 \times 7$ surface

26 Room temperature FI-STM and its applications

27 Scanning tunneling microscope equipped with a field ion microscope
Sakurai, T.

Hasegawa, Y.

Hashizume, T.

Kamiya, I.

Sumita, I.

Hyodo, S.

Ide, $T$.

Mizutani, T.

Matsui, J.

Ogawa, M.

Sakurai, $T$.

Hashizume, T.
Abstracts 4th Intl. Conf. on Scanning Tunneling Microscopy/ Spectroscopy STM '89, Oarai, Ibaraki, Japan
Abstracts 4th Inti. Conf. on Scanning Tunneling Microscopy/ Spectroscopy STM '89, Oarai, Ibaraki, Japan

Sakurai, I.

Hashizumi, T.

Kamiya, I.

Hasegawa, Y.

Ide, $\mathrm{T}$.

Miyao, M.

Sumita, I.

Sakai, A.

Hyodo, S.

Shedd, G.M.

J. de Phys. (1989)

Russell, P.E.

C8-50, 497-500

Ueda, $\mathrm{O}$.
J. Vac. Sci. Technol. (1989) A7, 1684-8

28 A walking, scanning tunneling microscope combined with a focused ion beam

29 Fabrication of stylus probes for scanning tunreling microscopy

Jpn. Kokai Tokkyo

Koho (1989), 4 
1 Consideration of rotational tunneling in rare-gas cluster ions

Alberton, C.R.

Chem. P. Lett. (1989)

Castleman, A.W.

157, 159-63

Ferguson, E.E.

Andion, N.P.

J. de Phys. (1989)

2 Conformal mapping for surface modeling

de Castilho, C.M.C. $\quad$ C8-50, 21-6

3 On charged-surface models and the origin of field adsorption

Forbes, R.G.

Surf. Sci. (1989) 223, 326-52

4 On different types of dipole-dipole interaction

Forbes, R.G.

J. de Phys. (1989)

C8-50, 15-20

5 Recent progress in LMIS theory

Forbes, R.G.

J. de Phys. (1989)

Ljepojevic, N.N.

C8-50, 3-8

6 A multidimensional tunneling theory with application to scanning tunneling microscope

7 Model study of tunneling times (Summary)

Huang, Z.H.

J. de Phys. (1989)

Cutler, P.H.

C8-50, 31-6

Feuchtwang, T.E.

Kazes, E.

Huang, Z.H.

J. de Phys. (1989)

Cutler, P.H.

Feuchtwang, T.E.

C8-50, 27-30

Kazes, E.

Nguyen, H.Q.

Sullivan, T.E.

8 Simulation of cross-correlation functions by a suspected soliton mechanism of alkali

Kleint, C.

J. de Phys. (1989)

C8-50, 47.52

submonolayer field emission noise

9 Thermal field desorption

Kreuzer, H.J.

J. de Phys. (1989)

Wang, L.C.

C8-50, 9-14

10 Tunneling time and effective capacitance for single

Laikhtman, B.

Wolf, E.L.

Phys. Lett. A (1989)

139, 257-60

electron-tunneling

11 Theory of a single-atom point source for electrons

Lang, N.D.

Yacoby, A.

Imry, $\mathrm{Y}$.
Phys. Rev. Lett.

(1989) 즈, 1499-502 
Theory

12 On the distribution function of surface charge density with respect to surface curvature

13 Comment on "field penetration and band bending near semiconductor surfaces in high electric field" by T.T. Tsong

14 Numerical calculation of the surface temperature of semiconductor tips in pulsed-laser AP-FIM

15 Formation of Ru-subcarbonyls in high electric field
Luo, E.

J. de Phys. (1989)

C8-50, 41-6

Tomita, M.

Kuroda, T.

J. de Phys. (1989)

C8-50, 37-40,

Tomita, $\mathrm{M}$.

Kuroda, T.

J. de Phys. (1989)

C8-50, 59-66

Wang, L.C.

Kreuzer, H.J.
J. de Phys. (1989)

C8-50, 53-8 
Addendum to Atom Probe Field Ion Microscopy and Related Topics:

A Bibliography for 1978-1987 and 1988

1 Stationary stochastic adparticle flip-flop as a precursor to surface diffusion

2 Representation of temperaturedependent spectral properties of adsorbate-induced emission noise by Lorentz functions

3 Application of FIM and atom probe to materials science mainly to radiation damage studies

4 On the theory of the equilibrium configuration and stability of an electrostatically stressed conducting fluid: application to liquid metal ion sources

5 Fundamentals of liquid metal ion sources: experiment, theory and applications

6 The effect of extraction voltage and beam voltage of a liquid metal ion source focused beam system on the current density in a focused spot

7 Oscillations and transient processes in liquid-metal ion emitters
Kleint, C.

Phys. Status Solidi A

(1979) $\underline{55}, 447-56$

Kleint, C.

Annalen der Physik

(1981) 38, 305-18

Igata, $\mathrm{N}$.

Sato, $\mathrm{S}$.

Proc. 6th Symp. on Ion Sources and Ion Assisted Technology (1982) Takagi, T., ed., Inst. Elec. Exprs.

Japan

Chung, $\mathrm{M}$.

Cutler, P.H.

Scanning Electron

Feuchtwang T. IV, 1547-56, SEM

Miskovsky, N.M. Inc., Chicago

Sujatha, N.

Mair, G.L.R.

Scanning Electron

Mulvey, T.

Microscopy (1984)

IV, 1531-40, SEM

Inc., Chicago

Orloff, J.

Scanning Electron

Microscopy (1984)

IV, 1541-46, SEM

Inc., Chicago

Dudnikov, V.G.

Shabalin, A.L.
Zh. Tech. Fiz. (1985)

55, 462 
Addendum to Atom Probe Field Ion Microscopy and Related Topics: Bibliographies for 1978-1987 and 1988

8 Helium field ion source for ion beam lithography

\author{
Horiuchi, $\mathrm{K}$. \\ Itakura, $\mathrm{T}$. \\ Yamamoto, $\mathrm{S}$.
}

Microcircuit

Engineering 84 (1985), 365-72, Heuberge, A. and Beneking, H., eds., Academic Press, London

Kingham, D.R. Bell, A.E.

Appl. Phys. (1985)

A36, 67-70

Gomer, R.

IBM J. Res. Develop. (1986) 30, 428-30

Fink, H-Wr.

IBM J. Res. Develop. (1986) $\underline{30}, 460-5$

Kleint, C.

Modinos, $\mathrm{A}$.

Surf. Sci. (1986) 177, 389-98

Luo, E.

J. Phys. D: Appl. Phys. (1986) $\underline{19}, 1-6$

Aidelberg, J. Seidman, D.N.

Mat. Sci. Forum (1987) $\underline{15-18}, 273-8$ uncorrelated long-range migs
of self-interstitial atoms in ordered alloys

15 Atomic resolution observations of radiation-damage profiles in ordered alloys

Aidelberg, J.

Mat. Sci. Forum

Seidman, D.N.

(1987) $\underline{15-18}, 1047-52$

Luo, E.

J. Phys. D: Appl.

Phys. (1987) 20, 1609 . function to the solution of boundary value problems 
Addendum to Atom Probe Field Ion Microscopy and Related Topics:

A Bibliography for 1978-1987 and 1988

17 Measurement of charge-to-mass ratio $(\mathrm{Q} / \mathrm{m})$ distribution of an ionized cluster beam by a special type of quadrupole mass analyzer

18 Proximal probes: gateway to the nanometer scale world

19 A study of martensite and its deformation and aging behavior in dilute uranium alloys using high-voltage electron microscopy and atom-probe field ion microscopy

20 Emission characteristics of field emission cathodes with localization of emission into small solid angles

21 Fabrication of niobium carbide nitride field emitter

22 Demonstration of simulated surface diffusion and application to auto- and cross-correlation FEFN measurements

23 Electron emission noise

24 Model study of supported bimetallic catalysts

25 Nucleation and coarsenirg of Beta-precipitates in $\mathrm{Cu}-1.75$ at \% Co solid solution
Nayak, D.

Pourrezaei, $\mathrm{X}$.

Francois, M.

Bahasadri, A.

Colton, R.

Murday, J.S.

Edmonds, D.V.

Fursey, G.N.

Bakhtizin, R.Z.

Ptitsyn, V.E.

Umagyzin, U.M.

Shvarkynov, B.A.

Ishizawa, Y.

Oshima, C.

Otani, S.

Koizumi, M.

Kleint, C.

Acta Universitatis

Wratislaviensis (1988)

$\underline{1025}, 143-53$

Kleint, C.

Surf. Sci. (1988) 200, 472-89

Knor, Z.

Sotola, J.

Collection

Czechoslovak Chem.

Commun. (1988) 53

2399-411

Liu, Z.

Guangjun, S.

Yong, $\mathrm{C}$.

Chinese Phys. Lett.

(1988) $\stackrel{5}{5} 537-40$

Rev. Sci. Instrum.

Nav. Res. Rev. (1988)

40, 2-12

Isr. J. Technol. (1988)

24, 555-66

Izv. Akad. Nauk.

SSR. Ser. Fiz. (1988)

$\underline{52}, 1250$

Jpn. Kokai Tokkyo

Koho (1988), 4

Duan, F. 
Addendum to Atom Probe Field Ion Microscopy and Related Topics: Bibliographies for 1978-1987 and 1988

26 A study of adsorption of $\mathrm{CO}$ on $\mathrm{Rh}$ surfaces with AP FIM

27 Cluster abundance spectra of germanium ions ejected from a liquid-metal ion source

28 Implantation studies of hydrogen by field ion microscopy and spectroscopy
Liu, W.

Ren, D.M.

Zhong, H.M.

Ye, S.X.

Zhou, F.M.

Wuhon, J.

Minami, $\mathrm{K}$.

Saito, Y.

Noda, $T$.

University (China)

(1988) 10, 15-22

Rapid Commun.

Mass. Spectrom.

(1988) $\underline{2}, 115-7$
Verink, E.D., Jr. DeHoff, R.T.

Hren, J.J.

(1988) 3, DOE/ER/45172-T1,

Order No.

DE88015806

(1988) 209,

DOE/ER/45172-T2,

Orcier No.

DE88016020

29 Microstructural characterization of wear resistant coatings

Vuorinen, S.

Skogsmo, J.

Yung, L.

high-resolution pulsed-laser

atom-probe

31 Nickel activated recrystallization of doped tungsten wire

Zonghe, L.

Norden, $\mathrm{H}$.

(1988) 102, Univ.

Microfilms Int., Order

No. DA8826783

Inst. Phys. Conf.

Surf. Modification

Technol. (1988), 143-

68 , Sudarshan, T.S. and Bhat, D.G., eds., Metall. Soc., TMS

Pittsburgh, Pa

Ser. 93 (1988) 2, 479 .

80 


\section{APPENDIX}

The reports and dissertations listed in the bibliography may generally be obtained through one of the following agencies:

National Technical Information

U.S. Department of Commerce

5285 Port Royal Road

Springfield, VA 21161 USA

Telephone: (703) $487-4650$

University Microfilms Int.

Dissertation Information Service

300 North Zeeb Road

Ann Arbor, MI 48106 USA

Telephone: (800) 521-3042 (Toll Free)

or (313) $761-4700$ 

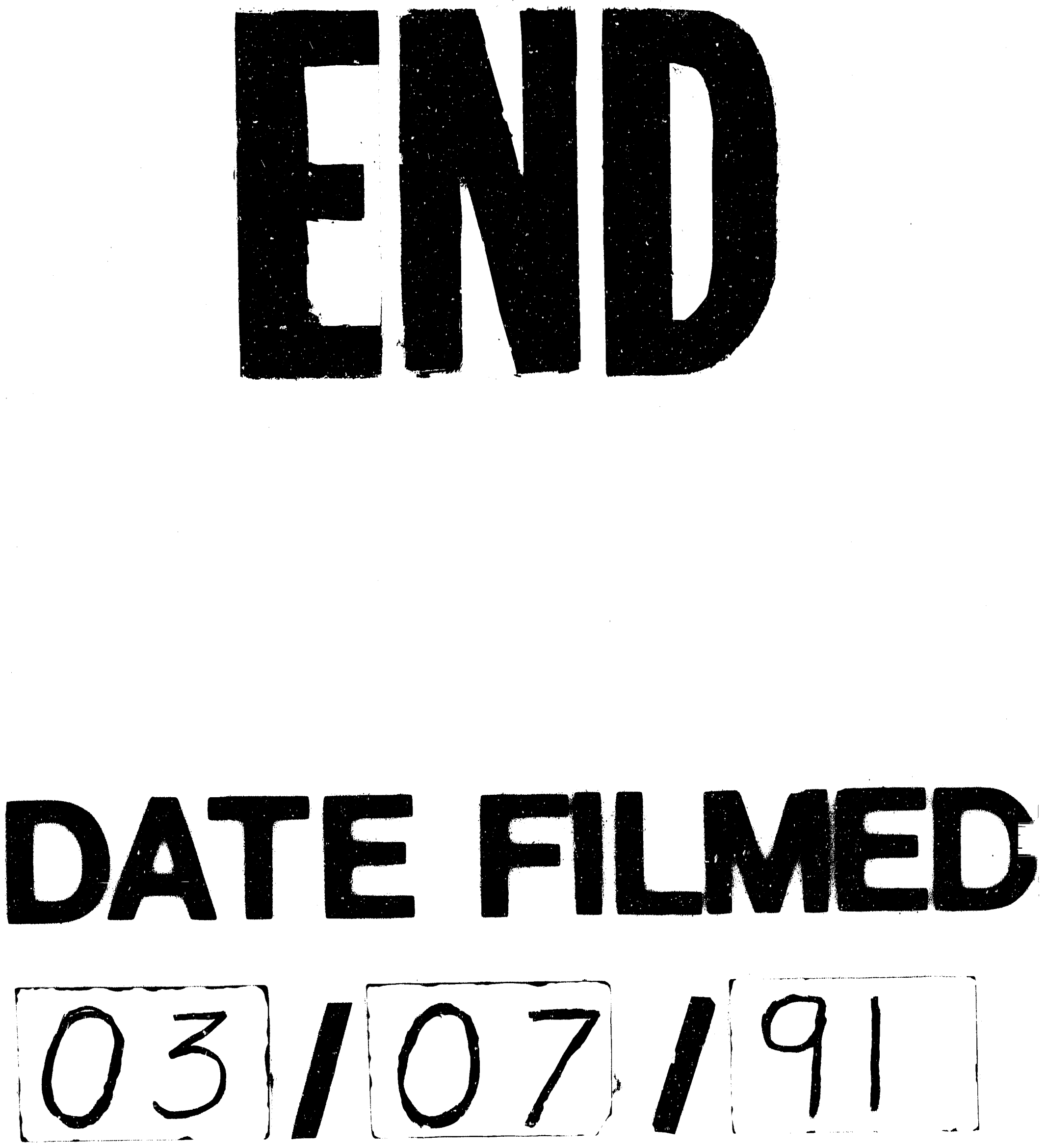
